\title{
Prevalence of Pathogenic Foodborne Bacteria from Beef in Retail Stalls in Kelantan
}

\author{
Fauzi F, Arshad MM, Ruhil HH, Al-Sultan II \\ Faculty of Veterinary Medicine, Universiti Malaysia Kelantan \\ Kampus Kota, Pengkalan Chepa, 16100 Kota Bharu, Kelantan \\ nnfazlina@gmail.com
}

\begin{abstract}
Salmonella, E. coli O157:H7, Methicillin-resistant Staphylococcus aureus (MRSA) and Listeria monocytogenes are common pathogenic foodborne bacteria causing foodborne illness in humans. The objective of this study was to determine the prevalence of those bacteria in beef from retail stalls in Kelantan. Beef samples were collected from retail stalls (roadside stalls and wet markets) and processed for the isolation and identification of Salmonella, E. coli O157:H7, MRSA and $L$. monocytogenes. Out of 25 beef samples from retail stalls, $11(44 \%)$ were positive for Salmonella, $11(44 \%)$ positive for E. coli and 8 (32\%) positive for S. aureus. None of the beef samples contained E. coli O157:H7, MRSA and L. monocytogenes. Of 11 Salmonella isolated, the most common were S. mbandaka (46\%), S. albany (36\%) followed by S. weltevreden (18\%). In this study, Salmonella, E. coli and S. aureus were found to be the most common foodborne bacteria from beef in retail stalls in Kelantan. Therefore, consumers have to practice a good safety foodhandling during purchasing, transporting and preparing the beef in the kitchen to prevent the risk of food poisoning.
\end{abstract}

Key Words: Salmonella, E. coli O157:H7, MRSA, L. monocytogenes, Beef

\section{INTRODUCTION}

In Kelantan, slaughtering of cattle in backyard slaughterhouse is commonly practiced compared to slaughter at the abattoir. This is because there are limited number of government abattoir and registered private abattoir in Kelantan. Thus, raw beef sold at the retail stores in Kelantan mostly originated from the backyard slaughterhouses.

From 2009 to 2010 the total numbers of foodborne disease outbreaks in the US were 1,527 (675 in 2009 and 852 in 2010). The outbreaks resulted in 29,444 cases of illness, 1,184 hospitalizations and 23 deaths (CDC 2013). Major foodborne bacteria that have been frequently reported to cause foodborne illness in humans include Salmonella spp., Escherichia coli O157:H7, Listeria monocytogenes and Staphylococcus aureus (Scallan et al. 2011). Foodborne illness caused by these bacteria had been frequently associated with the consumption of undercooked contaminated beef and foods containing beef (CDC 2008). In Malaysia, the incidence of food poisoning increased from 36.17 per 100,000 populations in 2009 to 43.28 per 100,000 populations in 2010 and to 57.06 per 100,000 population in 2011 (MOH 2009; 2010; 2011). However, in 2012, the incidence of food poisoning decreased to 44.93 per 100,000 populations and increased again in 2013, to 49.79 per 100,000 populations (MOH 2013). In 2010, there were 353 episodes of food poisoning, of which $43.6 \%$ occurred in schools. In 2011, 434 episodes of food poisoning were reported and of the 59.2\% episodes occurred in schools. However, the pathogen that caused the food poisoning was not reported. The most common risk factors for the food poisonings were inappropriate holding temperature and holding time (22.2\%) and untrained food handlers $(9.4 \%)$.

It is a common practice in Kelantan that the beef was sold unchilled without hanging the beef which enhances the multiplication of the pathogenic bacteria. Hence, consumers 
may be at higher risk of contracting beef foodborne illness. Besides, no published report has been found on the isolation and identification of pathogenic foodborne bacteria from raw beef from retail stores and slaughterhouses in Kelantan. The objective of this study is to determine the prevalence of foodborne bacteria (Salmonella, E. coli O157:H7, L. monocytogenes and $S$. aureus) in raw beef from retail stalls.

\section{MATERIAL AND METHODS}

\section{Study area and sample collection}

Beef samples were collected from retail stalls in the district of Kota Bharu, Bachok, Pasir Mas, Pasir Puteh and Tumpat. The thigh portion of the beef carcass was collected in a sterile whirl-pak bag and stored in ice-pack container. The samples were transferred immediately to the laboratory for further bacteriological analysis.

\section{Isolation and identification of Salmonella}

Twenty five $\mathrm{g}$ of beef sample was added to $225 \mathrm{ml}$ buffered peptone water (BPW) (Oxoid, Hampshire, UK). The mixture was homogenized for one minute at $230 \mathrm{rpm}$ and incubated at $37^{\circ} \mathrm{C}$ for $24 \mathrm{~h}$. Then $1 \mathrm{ml}$ of the $\mathrm{BPW}$ was transferred into $10 \mathrm{ml}$ tetrathionate broth and incubated at $42^{\circ} \mathrm{C}$ for $24 \mathrm{~h}$. A loopful of the broth was inoculated onto xylose lysine Tergitol 4 (XLT-4) agar (Oxoid, Hampshire, UK) and incubated at $37^{\circ} \mathrm{C}$ for $24 \mathrm{~h}$. Salmonella-suspected colony was inoculated into triple sugar iron (TSI) agar slant and incubated at $37^{\circ} \mathrm{C}$ for $24 \mathrm{~h}$. Culture suspension from TSI with typical Salmonella reactions was mixed with Salmonella polyvalent $\mathrm{O}$ antiserum (Difco, Ireland). Colonies with agglutination positive were confirmed as Salmonella. Salmonella isolates were sent to the Veterinary Research Institute Ipoh for serotyping.

\section{Isolation and identification of $E$. coli $0157: H 7$}

Twenty five $\mathrm{g}$ of beef sample was added to $225 \mathrm{ml}$ modified tryptose soya broth with novobiocin $(\mathrm{mTSB}+\mathrm{n})$ (Oxoid, Hampshire, UK). The mixture was homogenized for one minute at $230 \mathrm{rpm}$ and incubated at $37^{\circ} \mathrm{C}$ for $24 \mathrm{~h}$. A loopful of mTSB+n broth was inoculated onto sorbitol Mac-Conkey agar (Oxoid, Hampshire, UK) and incubated at $37^{\circ} \mathrm{C}$ for 24 h. E. coli colonies were further identified using latex agglutination test (Oxoid, Hampshire, UK) to confirm E. coli O157:H7.

\section{Isolation and Identification of L. monocytogenes}

Twenty five $\mathrm{g}$ of beef sample was added to $225 \mathrm{ml}$ listeria selective enrichment media (UVM) broth (Oxoid, Hampshire, UK). The mixture was homogenized for one minute at $230 \mathrm{rpm}$ and incubated at $37^{\circ} \mathrm{C}$ for $24 \mathrm{~h}$. Then $0.1 \mathrm{ml}$ of the UVM broth was transferred into $10 \mathrm{ml}$ Fraser broth (Oxoid; Hampshire, UK) and incubated at $37^{\circ} \mathrm{C}$ for $24 \mathrm{~h}$. A loopful of Fraser broth was inoculated onto Listeria selective agar (Oxoid; Hampshire, UK) and incubated at $37^{\circ} \mathrm{C}$ for $24 \mathrm{~h}$.

\section{Isolation and Identification of MRSA}

Twenty five $\mathrm{g}$ of beef sample was added to $225 \mathrm{ml}$ peptone water (Oxoid, Hampshire, UK). The mixture was homogenized for one minute at $230 \mathrm{rpm}$ and incubated at $37^{\circ} \mathrm{C}$ for 
$24 \mathrm{~h}$. A loopful of the peptone water was inoculated onto sheep blood agar (Acumedia, Lansing, MI) and incubated at $37^{\circ} \mathrm{C}$ for $24 \mathrm{~h}$. MRSA colonies were confirmed by catalase, coagulase test and PCR to detect mecA gene.

\section{RESULTS AND DISCUSSION}

The result of total plate count in this study was compared to the Malaysian regulatory standards for microbiological safety criteria in the Food Regulations 1985 (Laws of Malaysia 2010). According to these regulations, the acceptable limit for total plate count of fresh meat should not exceed $1.0 \times 10^{6} \mathrm{cfu} / \mathrm{g}$. However, the mean TPC in this study was $4.7 \times 10^{6} \mathrm{cfu} / \mathrm{g}$ and ranged from $7.0 \times 10^{3}$ to $1.8 \times 10^{7} \mathrm{cfu} / \mathrm{g}$ as determined by the analysis of variance (ANOVA). The high percentage of raw beef from retail stalls that had TPC above acceptable limit may due to the common practice in Kelantan where the beef sold mostly originated from the backyard slaughterhouses. This is because the hygienic practices at the backyard slaughterhouses are very low and could be initial factors of bacterial contamination on the beef. The bacteria continue to grow and expand by time in room temperature.

The bacterial isolates were identified as Salmonella, E. coli and S. aureus as shown on the Table 1. Of 25 beef samples from retail stalls, 11 (44\%) were positive for Salmonella spp, 11 (44\%) for E. coli and 8 (32\%) for S. aureus (Table 1). None of the isolates contained E. coli O157:H7, MRSA and Listeria spp.

Table 1. Prevalence of Salmonella, E. coli and S. aureus in beef from retail stalls

\begin{tabular}{lccc}
\hline \hline \multirow{2}{*}{ District (n) } & \multicolumn{3}{c}{ Bacteria isolates } \\
\cline { 2 - 4 } & Salmonella & E. coli & S. aureus \\
\hline Kota Bharu (11) & 4 & 5 & 4 \\
Bachok (3) & 1 & 1 & 1 \\
Pasir Puteh (5) & 3 & 1 & 3 \\
Pasir Mas (3) & 2 & 1 & 0 \\
Tumpat (3) & 1 & 3 & 0 \\
\hline Total (25) & 11 & 11 & 8 \\
\hline Total (\%) & 44 & 44 & 32 \\
\hline
\end{tabular}

Of 11 Salmonella isolates from retail stalls, the most common serotype was $S$. mbandaka (46\%) followed by S. albany (36\%) and S. weltevreden (18\%) (Table 2).

Table 2. Salmonella serotypes in beef from retail stalls

\begin{tabular}{lc}
\hline \hline Salmonella serotypes & Number of isolates (\%) \\
\hline S. mbandaka & $5(46)$ \\
S. albany & $4(36)$ \\
S. weltevreden & $2(18)$ \\
\hline Total & 11 \\
\hline
\end{tabular}

Salmonella isolates were most frequent to be present in the raw beef since this pathogen is widely disseminated in nature like water, soil and cattle itself. Most Salmonella outbreaks are associated with the use of contaminated products from animal 
origin (Wray \& Wray 2000) although non-food-borne Salmonella infection in humans may be transmitted during contact with animals, contaminated water or the environment. $S$. weltevreden was isolated from beef and was similar reported from Thailand (Bangtrakulnonth et al. 2004) and has been the most prevalent bovine Salmonella serovars in Vietnam (Vo et al. 2006). In Malaysia, food poisoning cases reported by the Ministry of Health for the year 1999, of 8,640 cases, 811 (9.4\%) were due to Salmonella (Thong et al. 2002). In addition, report of food poisoning from Division of Food Safety and Quality, Department of Health Kelantan showed the result in 2009, in 11 of 56 episodes (19.6\%), Salmonella was isolated from food samples collected during the outbreak investigation.

Staphylococcus aureus is the most prevalent pathogenic bacteria related to food poisoning (Scherrer et al. 2004). The main habitat of S. aureus is the human nasopharynx mucous membranes and animal skin (Lim 2010). S. aureus is also present in soil, water sources, dust and air (Quinn et al. 2002). The presence of S. aureus in foods that cause food poisoning is commonly related to improper handling by personnel, who are often contaminated with these microorganisms (Hatakka et al. 2000). As reported by Division of Food Safety and Quality, Department of Health Kelantan, S. aureus was the most frequent pathogen isolated from many cases of food poisoning happened in school canteen. In this study, the data could show that there is still no contribution of MRSA in food poisoning in Kelantan.

Okutani et al. (2004) reported that processed sliced and minced meat; and parts of intestine showed higher in L. monocytogenes contamination than whole pieces of meat. Several foodborne outbreaks of gastroenteritis, meningoencephalitis and/or abortion in humans around the world have been attributed to the consumption of dairy and beef products that were contaminated with L. monocytogenes (Mohammed et al. 2010).

In the United States, the annual incidence of listeriosis has been estimated at 2,500 cases and $20 \%$ at the fatality-case (Norton \& Braden 2007).

In this present study, no isolates of $E$. coli $\mathrm{O} 157: \mathrm{H} 7$ was isolated. However, other studies have reported the prevalence of E. coli O157:H7 in beef. Barkocy-Gallagher et al. (2003) has detected E. coli O157:H7 from 1.2\% of carcasses in commercial beef processing plants in the USA. Detection of E. coli 0157:H7 in the beef was still in very low number compared to other animals like pork (Ateba \& Mbewe 2011). Differences detection occurred between studies may result from different sampling and isolation methods and also variability in sampled populations.

\section{CONCLUSION}

This study demonstrates that Salmonella spp. were prevalent in beef from retail stalls in Kelantan and no E. coli O157:H7, MRSA and L. monocytogenes were isolated. The study also reveals that $E$. coli and $S$. aureus were prevalent in beef. The results suggest that, beef sold at retail stalls had already been contaminated with those organisms when they reach the stalls from slaughterhouses. Some precaution step should be taken especially for the butchers must use gloves to handle the beef since $S$. aureus also can be detected in the beef. As we know S. aureus is normal flora on human skin. Consumers should take safety steps to prevent food poisoning by choosing the retail stalls that hangs their beef rather than place on the table and store the beef in the refrigerator once it reached home to prevent the pathogenic bacteria from multiplying. 


\section{ACKNOWLEDGEMENT}

This research was supported by Universiti Malaysia Kelantan on a short term research grant (R/SGJP/A06.00/00443A/001/2010/000035). Appreciation is also given to Enforcement Division of DVS Kelantan for assisting in the collection of beef samples.

\section{REFERENCES}

Ateba CN, Mbewe M. 2011. Detection of Escherichia coli O157:H7 virulence genes in isolates from beef, pork, water, human and animal species in the northwest province, South Africa: Public health implications. Res Microbiol. 162:240-248.

Bangtrakulnonth A, Pornreongwong S, Pulsrikarn C, Sawanpanyalert P, Hendriksen RS, Lo Fo Wong DM, Aerestrup FM. 2004. Salmonella serovars from humans and other sources in Thailand, 1993-2002. Emerg Infect Dis. 10:131-136.

Barkocy-Gallagher GA, Arthur TM, Rivera-Betancourt M, Nou X, Shackelford SD, Wheeler TL. 2003. Seasonal prevalence of Shiga toxin-producing Escherichia coli, including O157:H7 and non-O157 serotypes and Salmonella in commercial beef processing plants. J Food Prot. 66:1978-1986.

CDC. 2008. Infectious disease weekly report infectious disease news-local (Vol. 4). Atlanta (USA): United States Department of Health and Human Services.

CDC. 2013. Morbidity and mortality weekly report surveillance for foodborne disease outbreaksUnited States, 2009-2010 (Vol. 62, pp. 41-47). http://www.cdc.gov/salmonella/ typhimurium01-13/index.html. Atlanta (USA): United States Department of Health and Human Services.

Genigeorgis CA. 1989. Present state of knowledge on Staphylococcal intoxication. Int J Food Microbiol. 9:327-360.

Hatakka M, Bjorkroth KJ, Asplud K, Maki-Petays N, Korkeala H. 2000. Genotypes and enterotoxicity of Staphylococcus aureus isolated from the hands and nasal cavities of flight catering employees. J Food Prot. 11:1487-1491.

Laws of Malaysia. 2010. Food Act 1983 (Act 281) \& Regulations. Selangor (Malaysia): International Law Book Services.

Lim SK, Nam HM, Park HJ, Lee HS, Choi MJ, Jung SC. 2010. Prevalence and characterization of methicillin-resistant Staphylococcus aureus in raw meat in Korea. J Microbiol Biotechnol. 20:775-778.

MOH. 2009. Malaysia health statistics. Kuala Lumpur (Malaysia): Ministry of Health Malaysia

MOH. 2010. Health facts 2009: Ministry of Health Malaysia

MOH. 2011. Health facts 2011: Ministry of Health Malaysia

MOH. 2013. Health facts 2013: Ministry of Health Malaysia

Mohammed HO, Atwill E, Dunbar L, Ward T, McDonough P, Gonzalez R, Stipetic K. 2010. The risk of Listeria monocytogenes infection in beef cattle operations. J Appl Microbiol. 108:349356.

Norton DM, Braden CR. 2007 Foodborne listeriosis. In: Listeria, Listeriosis, and Food Safety ed. Ryse ET, Marth E, editors. Boca Raton (USA): CRC press. p. 305-356.

Okutani A, Okada Y, Yamamoto S, Igimi S, 2004. Nationwide survey of human Listeria monocytogenes infection in Japan. Epidemiol Infect. 132:769-772.

Quinn PJ, Markey BK, Donnelly WJ, Leonard FC. 2002. Veterinary microbiology and microbial disease. Oxford (UK): Blackwell Publishing. 
Scallan E, Hoekstra RM, Angulo FJ, Tauxe RV, Widdowson MA, Roy SL. 2011. Foodborne illness acquired in the United States-major pathogens. Emerg Infect Dis. 17:7-15.

Scherrer D, Corti S, Muehlherr JE, Zweifel C, Stephen R. 2004. Phenotypic and genotypic characteristics of Staphylococcus aureus isolates from raw bulk-tank milk samples of goats and sheep. Vet Microbiol. 101:101-107.

Thong KL, Goh YL, Radu S, Noorzaleha S, Yasin R, Koh YT. 2002. Genetic diversity of clinical and environmental strains of Salmonella enterica serotype Weltevreden isolated in Malaysia. J Clin Microbiol. 40:498-503.

Vo ATT, Duijkeren EV, Fluit AC, Heck MEOC, Verbruggen A, Maas HME, Gaastra W. 2006. Distribution of Salmonella enterica serovars from humans, livestock and meat in Vietnam and the dominance of Salmonella typhimurium phage type 90. Vet Microbiol. 113:153-158.

Wray C, Wray A. 2000. Salmonella in domestic animals. New York (USA): CABI Publishing. 